\title{
Safety Factors Associated With Mathematics Achievement in South African Schools
}

\author{
Marien Alet Graham ${ }^{1 *}$, Mathelela Steyn Mokgwathi ${ }^{1}$, Johannes Jozua Rian de Villiers ${ }^{1}$ \\ ${ }^{1}$ Department of Science, Mathematics and Technology Education, University of Pretoria, SOUTH AFRICA
}

Received 27 April 2021 • Accepted 21 November 2021

\begin{abstract}
This study analysed secondary TIMSS 2019 data for respondents from South Africa and proposed a model containing ten constructs; nine independent variables (socio-economic status and eight variables about safety aspects in schools) and one independent variable (mathematics achievement). Qualitative data was also collected using interviews and field notes. The HLM model identified the following significant predictors to learners' mathematics achievement: learners whose family members were frequently insulted; who were victims of theft; who were forced to do things they didn't want to do; who were physically hurt; living in impoverished areas; enrolled in schools with a shortage of or inadequate instructional space; enrolled in schools where physical injury amongst learners is a problem; disrespecting property. Findings from the thematic analysis indicated that participants believed that schools' safety concerns are associated with learners' mathematics achievement and that difficulties in developing and implementing school safety policies are due to a lack of training.
\end{abstract}

Keywords: HLM, mathematics achievement, safety, TIMSS 2019

\section{INTRODUCTION}

There is growing global concern concerning South African mathematics learner achievement in schools. Studies such as Trends in International Mathematics and Science Studies (TIMSS) intend to explore aspects of mathematics achievement. Research studies have explored the socio-economic status (SES) and the safety aspects related to learners' mathematics achievement, finding both strong predictors of learner achievement (Kalaycıŏlu, 2015; Kanyongo \& Ayieko, 2017; Ker, 2016). In South Africa, low learner achievement in mathematics has occupied the centre stage yet again with the release of the TIMSS 2019 results. South Africa participated in TIMSS 2019 on Grade 5 and Grade 9 level, respectively; the focus of this study is at Grade 9 level and at this level, 39 countries participated, and South Africa was second from the bottom in mathematics achievement; only above Morocco (Reddy et al., 2020). These results are alarming, given that South Africa has had many intervention programmes aimed at improving the educational system over the last few years. The Gauteng Department of Education (GDE) introduced intervention projects such as the Dinaledi project (Blum et al., 2010) and the Secondary School Improvement Plan (SSIP) (Center for Education Innovations, n.d.), intending to improve learner achievement in mathematics amongst other subjects in the secondary schools. The Dinaledi project was launched in 2001 to improve mathematics performance and increase participation in maths; in 2012, the Dinaledi Unit was created to boost the project's work, particularly in teaching mathematics for girls. The SSIP was introduced to South African Grade 12 learners in 2010 and, since then, it was introduced to Grades 10 and 11 in 2011 and Grades 8 and 9 in 2012. Other strategies include, for example, the Gauteng Primary Literacy and Mathematics Strategy (GPLMS) aimed at strengthening the teaching of literacy and numeracy in Gauteng primary schools (GDE, 2012) and revising the Mathematics 1 curriculum in 2019 to ensure a greater alignment between schooling and university curriculum (Shay, 2020). Despite such initiatives by the Department of Basic Education (DBE) at both national and provincial, district and circuit level, South African mathematics learner achievement remains poor. Research has shown that lack of safety in schools may partly be responsible for low learner achievement in mathematics (Katschnig 


\section{Contribution to the literature}

- $\quad$ Safety aspects, identified in TIMSS 2019, associated with South African learner mathematics achievement were investigated. Data was also collected using interviews and field notes.

- Quantitative data identified significant predictors to learners' mathematics achievement: learners whose family members were insulted; victims of theft; forced to do things they didn't want to do or were physically hurt; living in impoverished areas; schools with resource shortages or where physical injury amongst learners is a problem; disrespecting property.

- Qualitative data indicated that participants believed that safety concerns are associated with learner performance and that difficulties in developing and implementing policies are due to a lack of training.

\& Hastedt, 2017; Zhang et al., 2019). Various aspects could be associated with low learners' mathematics achievement. These include teacher and learner perceptions of safety, shortage or inadequate resource allocations, overcrowding and school safety (Dabo, 2015; Juan \& Visser, 2017).

\section{Rationale of the Study}

Safety issues in South African schools are becoming a growing concern, and little research is available addressing safety and its association with learner achievement in mathematics. This study investigates the safety aspects as identified by the TIMSS in 2019, associated with learner achievement in mathematics in South African schools. A secondary analysis of the TIMSS 2019 data was undertaken to explore the underlying aspects of learner achievement in mathematics. Further data was collected through interviews and field notes to support the findings generated by the TIMSS 2019 data.

\section{Research Questions}

The primary research question is: How are the safety measures, as identified in TIMSS 2019, associated with South African Grade 9 learners' mathematics achievement?

The secondary research questions that support the primary research question are:

1. What are the principals' and teachers' perceptions on how safety measures are associated with teaching and learning in mathematics?

2. To what extent are safety aspects such as vandalism, theft, physical attacks, a shortage of or inadequate physical infrastructure in schools associated with learners' mathematics achievement?

3. What are the challenges schools experience in terms of safety?

\section{LITERATURE REVIEW}

\section{Literature Reviewed}

A lack of school safety is a phenomenon of great social interest; the importance of the phenomenon derives from the consequences it produces: poor academic achievement, anxious-depressive syndromes, sleeping disorders, behavioral disorders, verbal aggression, school absences, dropping out of school, suicidal behavior, delinquency, psychosomatic symptoms and substance abuse, among others (Bauman et al., 2013; Lereya et al., 2015, Rad et al., 2020; Williford et al., 2021). School safety is a global issue that requires a commitment from every nation in its working plans. Safety in schools go beyond feeling unsafe, dilapidated buildings and theft of property, to name a few; it even goes so far as violence to loss of life. Each year, around the world, approximately 246 million children are affected by school violence (United Nations Educational, Social and Cultural Organization [UNESCO], 2017).

Globally, there is a lot of research done on school safety, and we discuss a couple of recent publications. Hošková-Mayerová et al. (2021) focused on exploring schools' safety in the Czech Republic, specifically when it comes to terrorist attacks. Although they focus on the Czech Republic, they provide recent statistics (2000 2017) about terror attacks in schools and school facilities around the world. From their Figure 2, it can be seen that between the years 2000 to 2004, there were less than 50 terror attacks on schools and school facilities across the globe. However, from 2004 to 2012, there was a sharp increase, followed by a sharp decrease from 2012 to 2017. They argue that the decline might be due to increased security measures at schools and school facilities across the globe. Concerning their study of 46 nursery, elementary and secondary schools in the city of Brno, Czech Republic, they found that although 95\% of the schools have had theoretical and practical training, the theoretical training typically deals with occupational safety and health issues, whereas the practical training deals with issues such as efficiently evacuating learners from schools when, for example, there is a fire; neither the theoretical or practical training focuses on what to do in the case of, say, a terror attack. A lack of teacher 
training in school safety is not unique to the Czech Republic. In fact, this problem has been commonly reported across the globe. As an illustration, consider the study by Udali (2020), who investigated learners' and teachers' awareness of school safety measures in public secondary boarding schools in Trans-Nzoia County, Kenya. Udali (2020) used questionnaires, focus group interviews, document analysis and observation checklists, and the respondents included principals, teachers, students and security officers. Udali (2020) concluded that there was a low level of awareness of school safety measures among the teachers, students and security officers. Udali (2020) contributes this to the fact that the majority of students and staff have not received training on how to act in an emergency. Thus, a lack of training on how to handle security threats seems to be a problem across the globe. Knizhnikova (2019), who conducted a study in Russia on school safety, stated that violence committed by students in educational institutions have become more frequent over the last few years. Ruiz-Hernández et al. (2020) used a revised version of the 'Attitudes towards school violence' questionnaire to study attitude as a predictor of school violence. Their study involved 823 children aged between 10 and 17 years from 10 schools in the Region of Murcia, Spain. They found that attitudes towards violence are more present in males (compared to females) and in secondary school (compared to elementary school). Hamlin (2020) conducted a study in Detroit, Michigan, USA, by interviewing 31 parents and 23 teachers on parents' perceptions of school safety and on factors that parents perceive to be contributing to school safety, and found that a strong presence of parents on school grounds through, say volunteering, enhances safety by creating a positive school climate. This is similar to Hamlin and Li's (2020) finding that studied school safety in disadvantaged urban neighbourhoods in the United States of America and found that parents volunteering at schools led to less crime and violence in schools. Hamlin (2020) further found that other factors contribute to school safety, such as school building conditions and school location. It should be noted that Hamlin and Li (2020) conducted a secondary data analysis using existing data from the School Survey on Crime Safety, the Common Core Data, and the American Community Survey. Mohtar et al. (2019) conducted a secondary data analysis using TIMSS 2015 data to analyse the effect of safety aspects and bullying on science achievement in Malaysia and Japan and found that these factors significantly impacted science achievement. Lenzi et al. (2017) also conducted a secondary data analysis by using data from the California Healthy Kids Survey (CHKS) that were collected from 2010 to 2012 in Grades 7, 9 and 11, in Californian (USA) schools, and found that a sense of community and teacher support contributed to positive perceptions of school safety. Thus, using secondary data to examine school safety is common. We also do this in the current study; we use secondary data analysis (TIMSS 2019 data) to explore school safety in South Africa.

In South Africa, the National School Safety Framework (NSSF) was developed with the aim of addressing safety issues in schools. The NSSF requires teachers to perform many roles, such as creating and maintaining a safe school environment (Makota \& Leoschut, 2016) to promote school safety (Hanaya et al., 2020). However, the NSSF mechanisms seem to be falling short as violent attacks in South African schools is on the rise (Palm, 2019). For learners to achieve academic excellence, they must be free from the unsafe learning environment (Masitsa, 2011). Teachers and learners tend to focus on their safety instead of teaching and learning when they feel unsafe (Makungo, 2012). This could possibly ultimately translate into poor academic achievement as the attention has shifted from teaching and learning. Schools should be a safe haven where teaching and learning takes place, free from crime, violence and intimidation (Zhang et al., 2016). However, the frequent occurrence of incidents of violence reported in the media to date renders the South African schools unsafe (Baruth \& Mokoena, 2016; Luvhengo, 2020; Meyer, 2020; Palm, 2019). The School Infrastructure Safety and Security Guidelines (2017) reported that safety in South African schools is compounded by an increase in the wave of vandalism of school facilities, more specifically, the burning of schools, breaking of windows, theft of metal objects and electronic equipment as well as electrical cables among others.

For the international audience to understand the seriousness of safety problems within South African schools, some newspaper articles over the last year will be considered. On the 19 $9^{\text {th }}$ of March 2021, Mogomotsi Magome reported that a principal from the Eastern Cape was charged and arrested for child abuse after descending an 11-year-old learner into a pit toilet to retrieve his cell phone (Magome, 2021). In an article published on the $6^{\text {th }}$ of March 2021, Sihle Mlambo reported that six learners from Lenasia South Secondary were suspended due to a "violent school brawl" (Mlambo, 2021, para, 1). Earlier in March 2021, the Nombulelo Damba-Hendrik reported that Butterworth Masizame Junior Primary School, which is constructed out of mud, has one broken toilet that 175 learners and their teachers are sharing (Damba-Hendrik, 2021). What's worse is that several grades are sharing one classroom, which is poorly constructed, that during strong winds, learners are forced to flee the classroom in fear that the wind might remove the roof (DambaHendrik, 2021). On the $11^{\text {th }}$ of March 2021, Thami Magubane reported that more than 900 schools in KwaZulu-Natal schools have asbestos roofing which poses threats to the health of learners and staff (Magubane, 2021). Furthermore, a 16-year-old learner 
who attended Mount View High in Hanover Park is still struggling to find accommodation at a school since she was bullied and assaulted at the school for about two years (Ntseku, 2021). Earlier in February 2021, police officers from KwaZulu-Natal police explained that they are continuing their search for a learner who was allegedly kidnapped from his school in Durban after the 17-year-old learner was accused of stealing a cell phone belonging to his classmate (SABC news, 2021). Towards the end of the year 2020, Ofentse Ditlopo reported that learners at the Eqinisweni Secondary School protested, demanding better facilities after a part of the school building collapsed (Ditlopo, 2020). On the $26^{\text {th }}$ of November 2020, Tebogo Tsesane and Sibongile Teffo reported that more than 3000 schools in South Africa have pit latrines - whereby 500 of these schools are located in the Limpopo (Tsesane \& Teffo, 2020). The latter reporters explained that learners feel unsafe in these toilets and are forced to use bushes as toilet facilities (Tsesane \& Teffo, 2020). During the same month, in KwaZulu Natal, a sexual assault case was reported in which a geography teacher was sexually grooming one of his Grade 10 learners, as reported by Broughton (2020). The Grade 10 learner kept a trail of the conversations between her and the teacher, but the teacher claimed that he was a victim of conspiracy (Broughton, 2020). In the same province in October 2020, seven suspects were arrested after a compliance officer and a school principal were killed during a shooting (Chothia, 2020). A principal from Msinga in KwaZuluNatal was also gunned down while in his office, a teacher was hijacked, and a safety officer who was responsible for screening learners for COVID-19 symptoms was killed during violent outrages at schools in this province (Singh, 2020). Two learners from Mathole High School in this province were also suspended after they shared a video in which they attacked a fellow learner (Zulu, 2020). In another incident in September 2020, three teachers in the Mpumalanga province of South Africa were arrested after they assaulted learners aged 17 to 21 years (Grobler, 2020a). In March 2020, several incidents were also reported. For instance, on the $4^{\text {th }}$ of March 2020, Ntwaagae Seleka reported that a learner died and that six other learners were hospitalised after consuming tainted chocolate (Seleka, 2020). The next day, it was reported that learners from the North West province were rescued after the deputy principal locked them in a safe and left with the keys (Grobler, 2020b). The following day a Grade 10 learner died of a stab wound, schoolgirls were fighting, and gas was leaking in schools in Gauteng (Njilo, 2020); the gas leak was from a stove in a consumer study class and that some Grade 12 learner was rushed to a clinic (Grobler, 2020c). Earlier in the year 2020, a 15-year-old learner from Ecaleni School for learners with Special Needs in Tembisa in the Gauteng province was raped behind the classrooms by a fellow learner (Kempton Express, 2020). In another horrific case reported on the $29^{\text {th }}$ of January 2020, a principal of Graceland Education Centre was fired after one of her learners was raped and burnt to death after she had to walk from school since her school transport left her behind (Matlhare, 2020).

South African learners are continuously brutally assaulted and widespread of violence in schools despite all the security measures and mechanisms put in place in schools (Hendricks, 2019). Ncontsa and Shumba (2013) found that school violence has an effect on learners' loss of concentration in class and, subsequently, poor academic achievement. As evident from the discussions above, research overwhelmingly reports bullying, stabbing, violence, aggressive behaviour and murder when addressing safety in South African schools. Such research revealed the mounting evidence of a wide range of dire consequences such as cognitive stress, school disruptions and learner and teacher victimisations with the downward spiralling school safety issues and how such issues affect teaching and learning. According to Makota and Leoschut (2016), these consequences impact learners' overall academic achievement. Little research is available that explore the association between schools' safety policies and practices with learners' mathematics achievement. Therefore, research is required to explore how informed principals and teachers are regarding safety policies and practices in schools.

\section{Conceptual Framework}

This study was be guided by the conceptual framework model of Scheerens (2000) and Maslow's Hierarchy of Needs Theoretical framework (Maslow, 1943). The issue of safety in schools links to the input, process and output model of Scheerens and Maslow's hierarchy of needs theory with the feedback loop in this study. Scheerens's model is an input-process-output model with a multi-level structure that includes aspects at learner, classroom, school and education system levels. In this study, the input factors are the resources required to produce an outcome (output). The input factors, here it is safety aspects, are assumed to be related to the output (learner achievement) through process factors. The process factors are part of the so-called 'black box' as defined by Black and Wiliam (1998), in which teaching and learning takes place and in which inputs are transformed into outputs. Process factors can be divided into aspects at the school level, (e.g., school climate) and aspects at the classroom level (e.g., classroom climate). The process factors for this study are school location, safety policies and practices, safety in school, respect of property, physical infrastructure, vandalism, theft, physical attacks and classroom disturbance. Output factors refer to the end product from the production process. Mathematics learner achievement is the output factor of this study. It is assumed that the relation of input and process aspects 


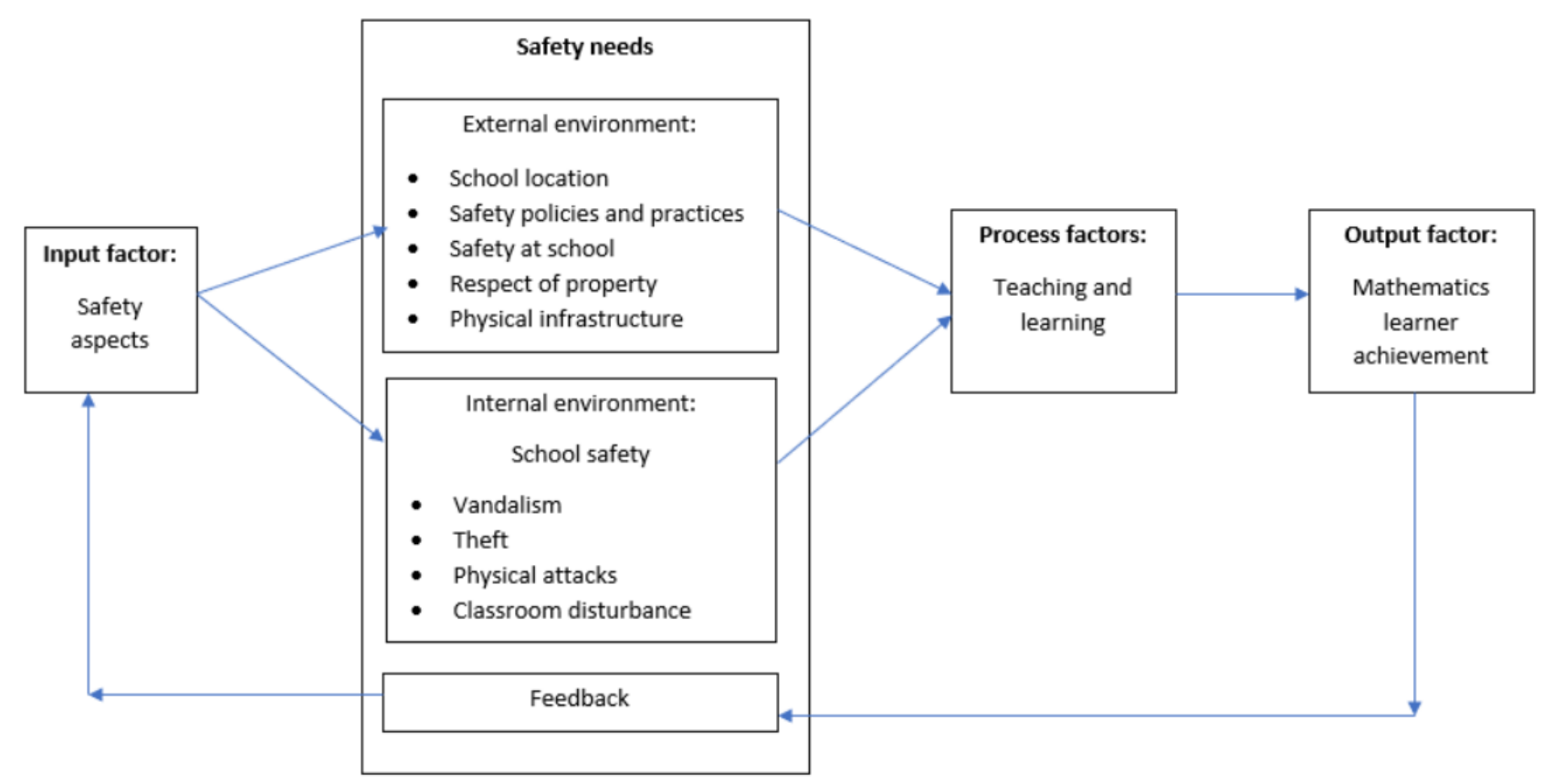

Note. Sourced from Scheerens (2000) as depicted in Scheerens et al. (2003), Licenced Under CC BY 4.0 (Dadeh, 2021, Figure 3.1) Figure 1. Modified conceptual framework of Scheerens (2000), and Maslow's Theory (1943)

with learner achievement is moderated by contextual aspects at system and school level (Scheerens, 2008). For this study's purpose, some adaptations were made to the original model of Scheerens. The external and internal environmental factors are incorporated with the feedback loop to the original model to develop an interactive model. The focus of the adapted model will be on the input factor (safety aspects), the school environment aspects (school location, safety policies and practices, safe at school, respect of property and physical infrastructure), the internal environment aspects (school safety include: vandalism, theft, physical attacks, classroom disturbance), the process factors (teaching and learning), and their association with the output factor (Grade 9 mathematics learner achievement). This adaptation narrows and focuses this study (Figure 1).

To enrich the study, Maslow's Hierarchy of Needs theoretical framework was also used in addressing the safety issues in schools. According to this theory, safety needs is a basic need that, if not met, will bring both the teachers and learners feeling anxious and tense. These needs need to be satisfied for teachers and learners to be free from any physical harm, hurt, loss of life and property loss or collapse so that a safe learning and teaching environment is created. Furthermore, this theory purports that lower needs must be satisfied before a higher need can be activated, and therefore, the assumption is that the physiological needs (learners have access to food, water) are met. This explains why physiological needs are not included in the revised model. In accordance with Maslow's hierarchy of needs theory, teachers and learners who are concerned about meeting the needs of safety cannot devote their full attention to teaching and learning in schools. Safety needs is a prerequisite for higher-order needs such as social needs (learners' sense of belonging and acceptance in the learning environment), self-esteem needs (learners are given opportunities to advance their learning) and self-actualisation needs (learners performing to their maximum potential). The safety needs need to be activated so that teachers can teach and learners can learn mathematics free from harm.

\section{METHOD}

An explanatory sequential mixed method design was followed, and an abduction research process was followed as this is typically used in mixed-methods research. In abductive inference, known premises are used to generate testable conclusions (Mitchell, 2018). Abductive reasoning addresses some of the weaknesses identified in deductive and inductive approaches by adopting a pragmatist perspective (Mitchell, 2018). Regarding the research strategy, for the quantitative phase, secondary data analysis was used, and for the qualitative phase, multiple case studies were used. Secondary data analysis refers to a research design that mostly use existing data, mostly quantitative data, to reapply and reanalyse such data to test hypotheses or to validate models (Mouton, 2001). Qualitative case study methodology provides tools for researchers to study complex phenomena within their contexts (Baxter \& Jack, 2008).

\section{Participants}

The quantitative phase is considered first. At Grade 8/9 level, 46 countries participated in TIMSS 2019. TIMSS 2019 made use of a two-stage stratified cluster 
sampling design (LaRoche et al., 2020) of Grade 8, who represented eight years of formal schooling, but South Africa chose ninth graders to better match their curricula. Firstly, schools were sampled according to their size and secondly, one or more intact classes from the target grade of each participating school were selected (LaRoche et al., 2020). For South Africa, the realised sample was 519 schools, 543 mathematics and science teachers and 20829 learners (Reddy et al., 2020). No permission was needed to analyse the TIMSS 2019 data, as the database is available for public use on their website (Fishbein et al., 2021).

For the qualitative phase, purposive sampling was used to select participants based on the unique qualities they possess, which, in this case, being principals and Grade 9 mathematics teachers in South African. South African schools are categorised into five groups called quintiles where Quintile 1 schools are the poorest and Quintile 5 schools are the most affluent (Van Dyk \& White, 2019). Quintiles 1 to 3 are "no-fee paying schools" whereas Quintiles 4 to 5 are "fee-paying schools". Six principals (three from no-fee-paying and three from feepaying schools) and 12 mathematics teachers (six from no-fee-paying and six from fee-paying schools) were interviewed. Their identities were kept confidential and pseudonyms were assigned as follows: $\mathrm{SCH} 1$ - SCH6 for the six schools, P if it's a principal, T1 - T12 for the 12 teachers, and $\mathrm{M}$ and $\mathrm{F}$ for male and female, respectively. For example, SCH1-T1-M indicates that the male participant is a teacher from the first school. Permission to conduct the interviews was obtained from the necessary authorities, the principals and the teachers.

\section{Data Collection and Instruments}

The quantitative phase is considered first. In this study, certain questions from the TIMSS 2019 questionnaires and the learners' mathematics achievement scores were used. The TIMSS 2019 developers went through many rigorous steps in developing the TIMSS 2019 achievement instruments. The assessment frameworks cannot drastically change from cycle to cycle but are routinely updated to keep up with fresh ideas and current information about curricula, standards, and instruction in mathematics and science education around the world. The interested reader is referred to Cotter et al. (2020) for a detailed account of this process. Focussing on the qualitative phase, the semi-structured interviews took place in March 2021 with principals and teachers from three schools. Interviews ranging between 30 to 45 minutes were conducted with six principals and twelve Grade 9 mathematics teachers (two per school). During March 2021, South Africa was on Lockdown Alert Level 1 (there are 5 levels with 5 being a full lockdown and 1 being the most lenient), and where participants felt save to be interviewed in-person, this was done. For the in-person interviews, field notes were also taken. Where participants did not feel comfortable meeting in-person, the interview was done online. All interviews were recorded.

\section{Quality Assurance}

For the quantitative data, the reader is referred to Martin et al. (2020) for details on how TIMSS 2019 ensure validity and reliability; details are omitted here for conciseness. For the qualitative data, triangulation was used in terms of multiple data sources (field notes and interviews), and the trustworthiness of the findings was ensured by member-checking; each participant received their transcript to check for accuracy. The final results were also sent to the participants to check for resonance with their experiences. Confirmability, which is concerned with the neutrality of the findings, was ensured by eliminating bias; this was done by making the participants feel accepted no matter what they answered (to avoid participant bias) and entering the process with an unbiased mind by ensuring pre-existing assumptions are kept at bay (to avoid researcher bias).

\section{Data Analysis}

For the quantitative phase of this study, for inferential statistics, the HLM version 7 statistical program was used to perform a two-level HLM analysis (Raudenbush \& Bryk, 2002) considering the hierarchical structure of the TIMSS 2019 data. Table 1 outlines the variables used in this phase. For the qualitative phase of this study, the audio recordings were transcribed verbatim. The qualitative data was coded using thematic analysis.

\section{RESULTS AND DISCUSSION}

The quantitative phase is considered first. Firstly, the null model containing no variables were created to show the difference between the schools in South Africa. Table 2 outlines the results of the null model. The variance of the null model is $49.73 \%(=3035.72$ / (3035.72 + 3068.15) * 100). Furthermore, the variance at school-level (Level2 ) is significantly different from zero, since the $p$-value is less than 0.05 ( $\mathrm{p}$-value < 0.001).

Secondly, the full model containing school and learner-level variables was created. This model shows the relationship between the selected variables and learner achievement. Table 3 shows the outcomes of the full model with a variance of $38.67 \%$. Moreover, the results show significance at school-level.

Thirdly, the final model was created. In this model, all the insignificant variables were removed one at a time, till only significant variables remained. Table 4 shows the results of the final model. 
Table 1. Summary of learner and school variables

Directory Variable Variable explanation

School-level predictors (level-2)

Teacher BTBG07A Thinking about your current school, indicate the extent to which you agree or disagree questionnaire with each of the following statements. This school is located in a safe neighborhood

BTBG07B Thinking about your current school, indicate the extent to which you agree or disagree with each of the following statements. I feel safe at this school

BTBG07C Thinking about your current school, indicate the extent to which you agree or disagree with each of the following statements. This school's security policies and practices are sufficient

BTBG07F Thinking about your current school, indicate the extent to which you agree or disagree with each of the following statements. The students respect school property

School BCBG03A Approximately what percentage of students in your school have the following

questionnaire backgrounds? Come from economically disadvantaged homes

BCBG13AC How much is your school's capacity to provide instruction affected by a shortage or inadequacy of the following? General School Resources: School buildings and grounds

BCBG13AE How much is your school's capacity to provide instruction affected by a shortage or inadequacy of the following? General School Resources: Instructional space

BCBG16F To what degree is each of the following a problem among Grade 9 students in your school? Vandalism

BCBG16G To what degree is each of the following a problem among Grade 9 students in your school? Theft

$\mathrm{BCBG16H}$ To what degree is each of the following a problem among Grade 9 students in your school? Intimidation or verbal abuse among students

BCBG16I To what degree is each of the following a problem among Grade 9 students in your school? Physical injury to other students

BCBG16J To what degree is each of the following a problem among Grade 9 students in your school? Intimidation or verbal abuse of teachers or staff

BCBG16K To what degree is each of the following a problem among Grade 9 students in your school? Physical injury to teachers or staff

Learner-level predictors (level-1)

Learner BSBG01 Are you a girl or a boy?

questionnaire BSBG13B What do you think about your school? Tell how much you agree with these statements. I feel safe when I am at school

BSBG14E During this school year, how often have other students from your school done any of the following things to you, including through texting or the Internet? Insulted a member of my family

BSBG14F During this school year, how often have other students from your school done any of the following things to you, including through texting or the Internet? Stole something from me

BSBG14G During this school year, how often have other students from your school done any of the following things to you, including through texting or the Internet? Made me do things I didn't want to do

BSBG14K During this school year, how often have other students from your school done any of the following things to you, including through texting or the Internet? Threatened me

BSBG14L During this school year, how often have other students from your school done any of the following things to you, including through texting or the Internet? Physically hurt me

BSBG14N During this school year, how often have other students from your school done any of the following things to you, including through texting or the Internet? Damaged something of mine on purpose

Table 2. The null model of South Africa

\begin{tabular}{lccccc}
\hline & Standard Deviation & Variance Component & df & Chi-square & p-value \\
\hline INTRCPT1, u0 & 55.09 & 3035.72 & 518 & 20543.57 & $0.000^{*}$ \\
Level-1, r & 55.39 & 3068.15 & & & \\
\hline
\end{tabular}

*Significant at a $5 \%$ level of significance

Table 3. The full model of South Africa

\begin{tabular}{lccccc}
\hline & Standard Deviation & Variance Component & df & Chi-square & p-value \\
\hline INTRCPT1, u0 & 42.85 & 1835.85 & 505 & 16056.72 & $0.000^{*}$ \\
Level-1, r & 53.95 & 2910.87 & & & \\
\hline
\end{tabular}

*Significant at a $5 \%$ level of significance 
Table 4. The final model of South Africa

\begin{tabular}{lccccc} 
& Standard Deviation & Variance Component & df & Chi-square & p-value \\
\hline INTRCPT1, u0 & 43.61 & 1901.47 & 513 & 16447.31 & $0.000^{*}$ \\
Level-1, r & 53.97 & 2912.72 & & & \\
\hline
\end{tabular}

*Significant at a $5 \%$ level of significance

Table 5. The significant predictors of the final model

\begin{tabular}{|c|c|c|c|c|}
\hline & Coefficient & $\begin{array}{l}\text { Standard } \\
\text { error }\end{array}$ & t-value & p-value \\
\hline Intercept & 381.80 & 3.55 & 107.34 & $0.000^{*}$ \\
\hline \multicolumn{5}{|l|}{ Level-1/learner-level (Learner predictors) } \\
\hline \multicolumn{5}{|l|}{$\begin{array}{l}\text { During this school year, how often have other learners from your school done } \\
\text { any of the following things to you, including through texting or the Internet: }\end{array}$} \\
\hline Insulted a member of my family (BSBG14E)** & -5.43 & 0.56 & 9.70 & $0.000^{*}$ \\
\hline Stole something from me (BSBG14F) & 6.42 & 0.51 & -12.65 & $0.000^{*}$ \\
\hline Made me do things I didn't want to do (BSBG14G) & -4.69 & 0.85 & 5.55 & $0.000^{*}$ \\
\hline Physically hurt me (BSBG14L)** & -5.89 & 0.76 & 7.74 & $0.000^{*}$ \\
\hline \multicolumn{5}{|l|}{ Level-2/school-level (School predictors) } \\
\hline $\begin{array}{l}\text { Approximate percentage of learners from schools hosting economically } \\
\text { disadvantaged homes (BCBG03A)*** }\end{array}$ & 27.91 & 4.70 & -5.93 & $0.000^{*}$ \\
\hline $\begin{array}{l}\text { How much is your school's capacity to provide instruction affected by a } \\
\text { shortage or inadequacy of the following? General school resources: } \\
\text { Instructional space (BCBG13AE)**** }\end{array}$ & 8.51 & 3.19 & -2.67 & $0.008^{*}$ \\
\hline $\begin{array}{l}\text { Thinking about your current school, indicate the extent to which you agree or } \\
\text { disagree with each of the following statement. The learners respect school } \\
\text { property (BTBG07F)***** }\end{array}$ & 11.31 & 2.71 & -4.16 & $0.000^{*}$ \\
\hline $\begin{array}{l}\text { To what degree is each of the following a problem among Grade } 9 \text { learners in } \\
\text { your school? }\end{array}$ & -13.04 & 5.25 & 2.48 & $0.013^{*}$ \\
\hline Intimidation or verbal abuse among learners $(\mathrm{BCBG} 16 \mathrm{H})^{* * * * * *}$ & & & & \\
\hline 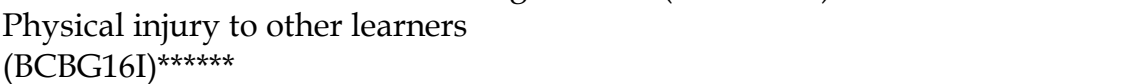 & 14.03 & 5.54 & -2.53 & $0.012^{*}$ \\
\hline
\end{tabular}

*Significant at a $5 \%$ level of significance

**Options: never, a few times a year, once or twice a month, at least once a week

*** Options: More than $50 \%, 26$ to $50 \%, 11$ to $25 \%, 0$ to $10 \%$

**** Options: A lot, some, a little, not at all

***** Options: disagree a lot, disagree a little, agree a little, agree a lot

****** Options: serious problem, moderate problem, minor problem, not a problem

The variance at the learner-level is 2912.72, which signifies $60.50 \%$ of the total variance. The variance at school-level (teacher and principal) is 1901.47 that represent $39.50 \%$ of the total variance which is statistically significant ( $p$-value $<0.001)$. The average reliability estimate was 0.96 , indicating that sample averages reflected the true school means. Table 5 shows the coefficients of the significant predictors of the final model.

The results from the level-1/learner-level showed the following:

- Learners that indicated that one of their family members were insulted 'at least once a week', including through texting or the Internet $(B=-5.43$, p-value <0.001) were outperformed by their counterparts ${ }^{1}$.

- Learners who indicated that something was stolen from them $(ß=6.42$, $p$-value $<0.001)$ 'at least once a week' outperformed those who indicated that nothing was 'never' stolen from them. This unexpected finding might be due to the wording of the question. The wording in the TIMSS questionnaire is "stolen something from me". In South African schools, it's not uncommon for learners to take small items from each other, like a ruler or an eraser (fact corroborated by interviews). Thus, we recommend that TIMSS consider changing this question to "stole something substantial from me", so that learners' understand that the question doesn't apply to something like a ruler or an eraser, but rather to a textbook or a calculator.

- Learners who reported that they were forced to do things that they did not want to do $(\Omega=-4.69$, pvalue <0.001) 'at least once a week' were outperformed by their counterparts.

${ }^{1}$ For all the level-1/learner-level results: Comparison made with lowest (benchmark) category = 'never' 
Table 6. Themes and sub-themes

Theme 1: School safety policy and procedures

Sub-theme 1.1: Knowledge of school safety policy

Sub-theme 1.2: Importance of school safety policy

Sub-theme 1.3: Stakeholder involvement in policy implementation and review

Theme 2: Safety aspects in schools association with learners' mathematics achievement

Sub-theme 2.1: Feeling of safety in schools

Sub-theme 2.2: Vandalism and theft

Sub-theme 2.3: Learner-to-learner and learner-to-teacher school-based violence

- Learners who reported that they were physically abused $(B=-5.89, p$-value $=0.002)$ 'at least once a week' achieved lower mathematics scores than their counterparts.

The results from the level-2/school-level showed the following:

- Learners who were taught at schools where the principal indicated that the school's capacity to provide instruction was 'not at all' affected by a shortage or inadequacy of instructional space $(ß=8.51$, $p$-value $=0.008)$ outperformed their counterparts ${ }^{2}$.

- Strangely, learners enrolled at schools where principals indicated that intimidation or verbal abuse among learners are 'not a problem' $(\beta=$ 13.04, $\mathrm{p}$-value $=0.013$ ) achieved lower mathematics scores than those enrolled at schools where the principal indicated that intimidation or verbal abuse among learners is 'a serious a problem' 3 . This unexpected finding might be due to the fact that intimidation or verbal abuse among South African learners is so common (Khumalo, 2019) that principals perhaps over-reported that it's a serious problem when, in fact, it's a common problem in South Africa. Another explanation to this finding could be due to the fact that principals might be under reporting intimidation and verbal abuse, since principals might see the reporting of intimidation and/or verbal abuse as a negative reflection on themselves and their leadership abilities.

- Learners enrolled at schools where principals indicated physical injury amongst learners are 'not a problem' $(\$=14.03$, p-value=0.012) outperformed learners enrolled at schools where principals indicated physical injury amongst learners is a serious problem.

- Learners who were taught by teachers who agreed a lot with the view that the learners respect the school's property $(ß=11.31, \quad$-value $<0.001)$ outperformed their counterparts ${ }^{4}$.
- Learners enrolled at schools that accommodated less than $10 \%$ of learners from economically disadvantaged homes $(\beta=27.91$, p-value $<0.001)$ achieved higher mathematics results than schools that accommodated more than $50 \%$ of learners from economically disadvantaged homes ${ }^{5}$.

For the qualitative analysis, a thematic analysis was conducted. Two main themes were identified and each theme had three sub-themes; these are summarised in Table 6.

Regarding Theme 1, school safety policy and procedures, the participants were asked whether they had a safety policy in place. From their responses, Sub-theme 1.1 emerged, namely, knowledge of school safety policy. The principals had thorough knowledge about it (its content, how often it is reviewed (which is typically annually), etc.); for example, SCH6-P-F stated that, "I am very much well informed. Safety means everything that have to do with safety of individuals, every person who enters the school premises. It speaks to how safe is the child in the environment. Safety in terms of health, safety in terms of language, safety in terms of bullying, safety in terms of human relation". However, the teachers haven't seen it or, if they have seen it, they didn't pay much attention to it. SCH1-T1-M stated that, "I saw it [the safety policy], but not really". SCH1-T2-M stated that, "You know, these policies, we hear about them, but we are not truly workshopped on it", but he goes on to say that there are some posters on the walls about, for example, bullying. The principals and teachers gave conflicting viewpoints because all the principals mentioned that the safety policies are provided to teachers, yet teachers' responses indicated that they "hear about them" [SCH1-T2-M] and that they have seen it, "but not really" [SCH1-T1-M]. One teacher indicated that they would like training on it and mentioned that it should not only be the SGB who gets training on the safety policies. One teacher indicated that he had never really paid attention to, or read, the safety policy, until COVID, "...it [the safety policy] came into play and played a big role now that there is this COVID-19" [SCH2-T2-M].

2 Comparison made with lowest (benchmark) category = 'a lot'

${ }^{3}$ Comparison made with lowest (benchmark) category $=$ 'serious problem'

${ }^{4}$ Comparison made with lowest (benchmark) category = 'disagree a lot'

${ }^{5}$ Comparison made with lowest (benchmark) category $=$ 'more than 50\%' 
The participants were asked about the importance of school safety policy and from their responses, Sub-theme 1.2 emerged, namely, importance of school safety policy. The majority of principals felt the school safety policy is of great importance; for example, SCH5-P-M stated that, that "the safety policy is the pillar of the school because it's the basis of everything". Out of the six principals, there was one that felt that school safety policy does not necessarily ensure safety for all. SCH4-P-M provided the following narration: "Safety policy plays a role to a certain extent, but I can't give $100 \%$ assurance". All the teachers reflected that the school safety policy plays an important role; for example, SCH4-T1-M believes that "[school safety] policies are there to ensure that rules and regulations are being followed so that we have minimal safety issues".

The participants were asked about the role that stakeholders play in school safety policy which led to Sub-theme 1.3, namely, stakeholder involvement in policy implementation and review. SCH2-T3-M mentioned that the school governing body (SGB) is not doing as much as they are supposed to, "The only job I've seen them [the SGB] do was to sign things". SCH1-T1-M stated that "we don't have a functional SGB", but then mentioned that the Gauteng Department of Infrastructure Development (Gauteng Department of Infrastructure Development, n.d.) sends people to fix things that are broken. The majority of participants mentioned that they have internal committees that consist of the principal, some members of the SGB and some teachers that try and address the challenges they face. In a South African setting, the SGB is defined as "A statutory body that governs the school and ensures it runs smoothly. Through the South African Schools Act, it gives the school principal and elected members the right to make policies around a range of issues that are in the best interests of the values and beliefs of the school" (South African Council for Educators [SACE], 2021, p. 6). What is disheartening, when hearing that the SGB is not doing their job, or not doing it to the best of their abilities, is the fact that the SGBs have the power to raise funds for the schools; the law allows for SGBs to raise funds (Nkosi, 2018). Raising funds is especially important for non-feepaying schools.

The participants were asked how safe they felt in schools, the challenges they had in terms of safety and how all this is associated with learners' mathematics achievement, which led to Theme 2, safety aspects in schools association with learners' mathematics achievement. Firstly, the participants were asked about whether they felt safe in schools which led to Sub-theme 2.1, namely, feelings of safety in schools, and all participants indicated that they felt safe in the schools during school hours in terms of no outsiders having access to the school, as all the schools had some form of security measures in place. A security guard was posted at the school entrance, and fencing around the school perimeter was present at all schools. This was clear from the researcher's observation (field notes); it was also mentioned by the participants, "Around the school perimeter, there is a palisade fence which is reinforced with razor wire at the top" [SCH1$\mathrm{T} 1-\mathrm{M}]$ and "We've got security personnel monitoring the grounds, and our grounds have been fenced" [SCH2-T3$\mathrm{M}]$.

When asked about the challenges that schools experienced in terms of safety, the answers led to Subthemes 2.2 and 2.3, respectively. For Sub-theme 2.2, vandalism and theft, all participants mentioned burglary and vandalism, especially over holidays and during the country-wide lockdown. Regarding the latter, COVID caused South Africa to be in lockdown for several months in 2020 and, during this time, schools were closed. During this lockdown period, all the schools included in this study were broken into or vandalised. One principal, SCH2-P-F, mentioned that during the COVID-lockdown period, the electricity cables were stolen (cable theft). Further, in terms of safety in schools, participants mentioned broken ceilings, windows, chairs and desks. SCH1-T1-M stated that, "They break the desk and the chairs. Also, they vandalise the ceiling, they break the windows". SCH2-T3-M stated that "the circuit breakers, they have been stolen, sometimes the lights" and also explained that learners don't bring their textbooks or calculators to school because they will just get stolen. According to the participants, this happens frequently and leads to frustration, as SCH1-P-F expressed that "because your government funding does one thing all the time, over and over", referring to replacing broken ceilings, windows, desks, chairs and stolen circuit breakers, etc., over and over again. Since Sub-theme 2.2, vandalism and theft, relates to theft, it is worth noting that because we conducted the quantitative analysis before the qualitative analysis, we were aware of the fact that learners who had reported something stolen once a week in the TIMSS 2019 data performed significantly higher in mathematics. When asking the participants to comment on this finding, the responses were that theft, especially of small items, are so common in South African schools, that the question may have been viewed differently in a South African context as opposed to countries where theft, even of small items, are not a problem. Also relating the Sub-theme 2.2., in the researcher's field notes, there were notes about seeing broken ceilings and windows. For Sub-theme 2.3, learner-to-learner and learner-to-teacher school-based violence, the principals were asked about the incidence of teachers' and learners' injuries reported at school and how such incidence may be associated with learners' mathematics achievement. Interestingly, no report of injuries to teachers was reported in any of the six schools in the last three years. For example, SCH2-P-F stated, "I have not had a case of teacher injury. The last incident of learner-to-teacher was in 2019 where a Grade 9 learner wanted to manhandle the teacher; fortunately, 
colleagues came in and assisted with the impasse". It is apparent that teachers are generally safe from injuries at school based on the responses provided by all six principals; however, injuries to learners remains a great concern in four of the six schools. SCH5-P-M clearly stated, "We used to have a lot of fights, and it was happening nearly every day. I would say no, it won't have an influence on maths achievement as there are no more fighting in the school". SCH6-P-F reiterated the statement by SCH5-P-M by explaining that: "When the school started in February this year, one of my learners stabbed the other one with a screwdriver. No, I'm saying "no" with inverted commas because I would not say we've got anything specific that would say there is violence in such a way that mathematics learners would be influenced or affected by that". Regarding the principals' and teachers' perceptions on whether these issues mentioned in Sub-themes 2.2 and 2.3 are associated with teaching and learning in mathematics, the majority of principals and teachers mentioned that there is a negative association and there is lack of safety in schools. The arguments included "If a learner is bullied, that learner would be afraid to come to school ... the learner misses school as a result" [SCH3-T5-F] and "because if a learner's book is stolen, it means everything is gone ... the learner needs to start from scratch" [SCH1P-F].

The latter speaks to SES and SES also featured in the quantitative findings since the percentage of economically disadvantaged students at schools (BCBG03A) was found to have the strongest relationship to mathematics achievement. It's clear that SES relates strongly to safety issues. Research has shown that a healthy and safe school climate is associated with improved learner academic achievement, which reduces the academic achievement gaps between learners in schools of different SES backgrounds (Berkowitz et al., 2017; Jones \& Shindler, 2016).

\section{LIMITATIONS}

We acknowledge that this study is based on nonexperimental data, and causal interpretations of relationships could not be drawn. Further research using experimental designs potentially could test whether improvements in school climate through planned interventions actually result in higher achievement compared to control schools. We acknowledge that the qualitative data was collected during various lockdown restriction levels in a year that was not a typical school year due to COVID-19. The quantitative data was collected in 2018 (TIMSS data were collected in the Southern Hemisphere in September 2018 (Cotter et al., 2020)), and the qualitative data was collected in March 2021. We could, unfortunately, not wait for the next TIMSS cycle, as one of the author's doctoral studies are based on this study and he had to complete and submit his thesis.

\section{CONCLUSION}

This study investigated the safety aspects, as identified by the TIMSS in 2019, associated with learner achievement in mathematics in South African schools. A secondary analysis of the TIMSS 2019 data was undertaken to explore the underlying aspects of learner achievement in mathematics. Further data was collected through interviews to support the findings generated by the TIMSS 2019 data. The quantitative results showed that the following were significant predictors of learners' mathematic achievement: learners whose family members were frequently insulted; learners who were victims of theft; learners who were forced to do things they didn't want to do; learners who were physically hurt; learners living in impoverished areas; learners enrolled in schools with a shortage of or inadequate instructional space; learners enrolled in schools where physical injury amongst learners are a problem; learners disrespecting property. The qualitative results showed that participants believed that schools' safety concerns can contribute to low learner performance and that most teachers were not informed on the content of the safety policy and would like to receive training on safety aspects.

\section{RECOMMENDATIONS}

School safety must be made a policy and funding priority. The participants mentioned funding as a problem, as they are using the funds to replace the same things over and over again that have been stolen or broken (see Sub-theme 2.2). To fully develop staff capacity and effectively implement school safety management, it is recommended that governments make school safety a policy and funding priority. Although the South African government has recently made education a priority, their focus is more on elearning (evident from projects such as White Paper 7 on e-Education of 2004) than on safety. Thus, it is recommended that sufficient funds be allocated in education budgets to safety in schools.

From Sub-theme 1.1, it was evident that some teachers had not even seen the school safety policies as they mentioned that they've heard of it, i.e. they were aware of its existence; however, they haven't seen it. Accordingly, it is recommended that principals ensure that every teacher receives a copy of the safety policies and ensure that they study it thoroughly by having some informal assessment and/or professional development training on its content. The assessment could be in a written form or even, more informally, just a simple conversation between the principal and the teacher on the content of the safety policies for the principal to ensure that all the teachers have adequate knowledge on it. Or it can take on a more formal approach where newly appointed teachers are sent on a professional 
development training course relating to the school's safety policies.

Develop workforce capacity. Participants reported difficulties developing and implementing school safety policies due to a lack of training and understanding (see, for example, Sub-theme 1.1 where participants mention they are not "workshopped" on the safety policy). Therefore, it is recommended that workforce capacity be developed and that learner and teacher participation in school safety management should be increased. Hence, increasing learner participation in school safety management, as well as systematically incorporating school safety management into pre-service and inservice training, is recommended.

The final recommendation is that since SES is the most significant predictor of learners' mathematics achievement (see multi-level model), and learners in high poverty schools have significantly lower mathematics achievement than those in higher SES backgrounds, is to try and make the schools in high poverty areas as safe as possible, as research has shown that a healthy and safe school climate is associated with improved learner academic achievement which reduces the academic achievement gaps between learners in schools of different SES backgrounds (Berkowitz et al., 2017; Jones \& Shindler, 2016).

Author contributions: All authors have sufficiently contributed to the study, and agreed with the results and conclusions.

Funding: The first author's research was funded by the National Research Foundation (NRF) [Reference: CSRP190415430728, Grant number: 120401]

Declaration of interest: No conflict of interest is declared by authors.

\section{REFERENCES}

Baruth, G. D., \& Mokoena, S. (2016). A framework to deal with violence in South African public schools. International Journal of Educational Sciences, 12(2), 96105.

https:/ / doi.org/10.1080/09751122.2016.11890416

Bauman, S., Toomey, R. B., \& Walker, J. L. (2013). Associations among bullying, cyberbullying, and suicide in high school students. Journal of Adolescence, 36(2), 341-350. https:/ / doi.org/10.1016 /j.adolescence.2012.12.001

Baxter, P., \& Jack, S. (2008). Qualitative case study methodology: Study design and implementation for novice researchers. The Qualitative Report, 13(4), 544-559. https://doi.org/10.46743/2160-3715/ 2008.1573

Berkowitz, R., Moore, H., Astor, R. A., \& Benbenishty, R. (2017). A research synthesis of the associations between socioeconomic background, inequality, school climate, and academic achievement. Review of Educational Research, 87(2), 425-469. https:// doi.org/10.3102/0034654316669821
Black, P., \& Wiliam, D. (1998). Inside the black box: Raising standards through classroom assessment. Phi Delta Kappan, 80(2), 139-148.

Blum, J., Krishnan, N., \& Legovini, A. (2010). Expanding opportunities for South African youth through math and science: The impact of Dinaledi Program. World Bank. http:/ /hdl.handle.net/10986/19009

Broughton, T. (2020, November 5). Pupil outwits KZN teacher who tried to 'sexually groom' her. Sunday Times. https://www.timeslive.co.za/sundaytimes-daily / news / 2020-11-05-pupil-outwits-kznteacher-who-tried-to-sexually-groom-her/

Center for Education Innovations. (n.d.). Secondary school improvement programme (SSIP). https://Www. educationinnovations.org/p/secondary-schoolimprovement-programme-ssip

Chothia, A. (2020, October 24). Seven arrested following fatal shootings at two KZN schools. The South African. https://www.thesouthafrican.com/news/twokilled-kzn-school-shooting/

Cotter, K. E., Centurino, V. A. S., \& Mullis, I. V. S. (2020). Developing the TIMSS 2019 mathematics and science achievement instruments. In M. O. Martin, M. von Davier, \& I. V. S. Mullis (Eds.), Methods and procedures: TIMSS 2019 technical report (pp. 1.1-1.36). TIMSS \& PIRLS International Study Center, Lynch School of Education and Human Development, Boston College and International Association for the Evaluation of Educational Achievement. https:// timssandpirls.bc.edu/timss2019/methods / chapter-1.html

Dabo, J. I. (2015). The effect of teacher-pupil ratio on teaching learning process in Bauchi State primary school. International Journal of Science, Environment and Technology, 4(4), 1218-1225.

Dadeh, T. H. (2021). Exploring school climate and Indonesian Year 8 students' mathematics learning outcomes: A mixed method study [Doctoral dissertation, University of Bristol]. Explore Bristol Research.http:/ / research-information.bristol.ac.uk

Damba-Hendrik, N. (2021, March 12). Mud school has one broken toilet for 175 learners and staff. GroundUp. https://www.groundup.org.za/article/notschool-grave-says-eastern-cape-parent/

Ditlopo, O. (2020, November 22). Learners raise concerns about the safety of their school in Ivory Park. Midrand Reporter. https:/ / midrandreporter.co.za/277139/ scared-of-a-collapse/

Fishbein, B., Foy, P., \& Yin, L. (2021). TIMSS 2019 user guide for the international database (2nd ed.). TIMSS \& PIRLS International Study Center. https:/ / timss2019.org/international-database/

Gauteng Department of Education (2012, March 11). Gauteng Department of Education launches plan to improve language and maths skills for grades 4-7. 
Gov.za.

https:/ / www.gov.za/gautengdepartment-education-launches-plan-improvelanguage-and-maths-skills-grades-4-7

Gauteng Department of Infrastructure Development (n.d.). Department of infrastructure development. Gauteng.gov.za. https://www.gauteng.gov.za/ Departments/DepartmentInstitution/\%7B29A092 BE-EED8-4A17-AA08-25661B3DFC22\%7D? departmentId=CPM-001008

Grobler R. (2020c, March 06). Grade 12 pupils rushed to clinic following gas leak in Tshwane classroom. News24. https://www.news24.com/news24/ southafrica/news/north-west-pupils-rescuedafter-deputy-principal-locks-them-in-safe-andleaves-report-20200305

Grobler, R. (2020a, September 02). Corporal punishment: 3 Mpumalanga teachers arrested for 'assaulting' pupils. News24. https://www.news24.com/news24/ southafrica/news/corporal-punishment-3mpumalanga-teachers-arrested-for-assaultingpupils-20200902

Grobler, R. (2020b, March 05). North West pupils rescued after deputy principal 'locks them in safe' and leaves. News24. https://www.news24.com/news24/ SouthAfrica/News / grade-12-pupils-rushed-toclinic-following-gas-leak-in-tshwane-classroom20200306

Hamlin, D. (2020). Flight to safety in deindustrialised cities: Perceptions of school safety in charter and public schools in Detroit, Michigan. Education and Urban Society, 52(3), 394-414. https://doi.org/10.1177/0013124519846288

Hamlin, D., \& Li, A. (2020). The relationship between parent volunteering in school and school safety in disadvantaged urban neighborhoods. Journal of School Violence, 19(3), 362-376. https: / / doi.org/10.1080/15388220.2019.1700801

Hanaya, A., McDonald, Z., \& Balie, L. (2020). Teacher agency in South African education policy related to school safety. Africa Education Review, 17(1), 1-17. https:/ / doi.org/10.1080/18146627.2018.1467734

Hendricks, E. A. (2019). The effects of the exposure to violence in schools on the psychological well-being of learners in the Sarah Baartman District Municipality, Eastern Cape. African Journal of Social Work, 9(2), 1-9.

Hošková-Mayerová, Š., Bekesiene, S., \& Beňová, P. (2021). Securing schools against terrorist attacks. Safety, 7(1), Article 13, 1-18. https://doi.org/ $10.3390 /$ safety7010013

Jones, A., \& Shindler, J. (2016). Exploring the school climate--student achievement connection: Making sense of why the first precedes the second. Educational Leadership and Administration: Teaching and Program Development, 27, 35-51.
Juan, A., \& Visser, M. (2017). Home and school environmental determinants of science achievement of South African students. South African Journal of Education, 37(1), Article 1292, 1-10. https:/ / doi.org/10.15700/saje.v37n1a1292

Kalaycıoğlu, D. B. (2015). The influence of socioeconomic status, self-efficacy, and anxiety on mathematics achievement in England, Greece, Hong Kong, the Netherlands, Turkey, and the USA. Educational Sciences: Theory $\mathcal{E}$ Practice, 15(5), 1391-1401. https:/ / doi.org/10.12738/estp.2015.5.2731

Kanyongo, G. Y., \& Ayieko, R. (2017). Hierarchical linear modelling of sixth-grade students' socio-economic status and school factors on mathematics achievement: Case studies of Kenya and Zimbabwe. African Journal of Research in Mathematics, Science and Technology Education, 21(2), 187-199. https:/ / doi.org/10.1080/18117295.2017.1334368

Katschnig, T., \& Hastedt, D. (2017). Too scared to learn? Understanding the importance of school safety for immigrant students. Policy Brief No. 15. International Association for the Evaluation of Educational Achievement.

Kempton Express (2020, February 13). Autistic learner (15) allegedly raped at Ecaleni school. Kempton Express. https://kemptonexpress.co.za/274087/ autistic-learner-15-allegedly-raped-ecaleni-school

Ker, H. W. (2016). The impacts of student-, teacher- and school-level factors on mathematics achievement: An exploratory comparative investigation of Singaporean students and the USA students. Educational Psychology, 36(2), 254-276. https:/ / doi.org/10.1080/01443410.2015.1026801

Khumalo, S. S. (2019). Implications of school violence in South Africa on socially just education. e-Bangi: Journal of Social Sciences and Humanities, 16(8), 1-11. https: / / ejournal.ukm.my/ebangi/article/viewFil e/34835/9766

Knizhnikova S.V. (2019). Amok: Relevance of school attacks exploring, causes, and primary prevention possibilities. Sotsial'naia psikhologiia $i$ obshchestvo [Social Psychology and Society], 10(1), 152-168. https://doi.org/10.17759/sps.2019100109

LaRoche, S., Joncas, M., \& Foy, P. (2020). Sample design in TIMSS 2019. In M. O. Martin, M. von Davier \& I. V. S. Mullis (Eds.), Methods and procedures: TIMSS 2019 Technical Report (pp. 51-83). TIMSS \& PIRLS International Study Center.

Lenzi, M., Sharkey, J., Furlong, M. J., Mayworm, A., Hunnicutt, K., \& Vieno, A. (2017). School sense of community, teacher support, and students' school safety perceptions. American Journal of Community Psychology, 60(3-4), 527-537. https://doi.org/ 10.1002/ajcp.12174 
Lereya, S. T., Copeland, W. E., Zammit, S., \& Wolke, D. (2015). Bully/victims: A longitudinal, populationbased cohort study of their mental health. European Child $\mathcal{E}$ Adolescent Psychiatry, 24(12), 1461-1471. https: / / doi.org/10.1007/s00787-015-0705-5

Luvhengo (2020, February 7). School bullying indicative of high violence levels in SA. Times Live. https: / / www.timeslive.co.za/news/southafrica/2020-02-07-school-bullying-indicative-ofhigh-violence-levels-in-sa/

Magome, M. (2021, March 19). South Africa headmaster charged for sending boy into latrine. Sunday Times. https://abcnews.go.com/International/wireStory / south-africa-headmaster-charged-sending-boylatrine-76509942

Magubane, T. (2021, March 11). Asbestos school roofs pose potential health risks. IOL News. https://www.iol. co.za/mercury / news/asbestos-school-roofs-posepotential-health-risks-5530f630-cacd-4ca0-92c7c29f47439243

Makota, G., \& Leoschut, L. (2016). The national school safety framework: A framework for preventing violence in South African schools. African Safety Promotion: A Journal of Injury and Violence Prevention, 14(2), 18-23.

Makungo, A. N. (2012). Challenges faced by the school management team (SMT) regarding school safety [Master's dissertation, University of Pretoria]. UPSpace Repository.

Martin, M. O., von Davier, M., \& Mullis, I. V. (2020). Methods and procedures: TIMSS 2019 technical report. International Association for the Evaluation of Educational Achievement.

Masitsa, M. G. (2011). Exploring safety in township secondary schools in the Free State province. South African Journal of Education, 31(2), 163-174. https:/ / doi.org/10.15700/saje.v31n2a477

Maslow, A. H. (1943). A theory of human motivation. Psychological Review, 50(4), 370-396. https:/ / doi.org/10.1037/h0054346

Matlhare. A. (2020, January 29). Principal removed from school following pupil's brutal rape, murder. The Star. https:/ / www.iol.co.za/the-star/news/principalremoved-from-school-following-pupils-brutalrape-murder-41649539

Meyer, D. (2020, February 21). School violence: Another pupil stabbed as death toll climbs to 16 . The South African. https://www.thesouthafrican.com/news / school-violence-student-stabbed-gauteng-2020/

Mitchell, A. (2018). A review of mixed methods, pragmatism, and abduction techniques. The Electronic Journal of Business Research Methods, 16(3), 103-116.

Mlambo, S. (2021, March 17). Six Lenasia South Secondary pupils suspended after violent school brawl. IOL News. https://www.iol.co.za/news/south-africa/ gauteng/six-lenasia-south-secondary-pupilssuspended-after-violent-school-brawl-b68b4792ac00-41e4-9dc1-7d42a345ee02

Mohtar, L. E., Halim, L., Samsudin, M. A., \& Ismail, M. E. (2019). Non-cognitive factors influencing science achievement in Malaysia and Japan: An analysis of TIMSS 2015. EURASIA Journal of Mathematics, Science and Technology Education, 15(4), em1697. https:/ / doi.org/10.29333/ejmste/103567

Mouton, J. (2001). How to succeed in your Master's and Doctoral studies: A South African guide and resource book. Van Schaik.

Ncontsa, V. N., \& Shumba, A. (2013). The nature, causes and effects of school violence in South African high schools. South African Journal of Education, 33(3), Article 671, 1-15. https://doi.org/10.15700/ 201503070802

Njilo, N. (2020, March 06). Grade 10 pupil succumbs to stab wound, schoolgirl fight, and gas leak: Week in Gauteng education. Times Live. https://www.timeslive.co. za/news / south-africa/2020-03-06-grade-10-pupilsuccumbs-to-stab-wound-schoolgirl-fight-and-gasleak-week-in-gauteng-education/

Nkosi, B. (2018, May 30). Please sir, may we have some more teachers. The Star. https://www.iol.co.za/news/ south-africa/gauteng/please-sir-may-we-havesome-more-teachers-15234653

Ntseku, M. (2021, March 4). Family battling to find school placement for bullied and abused Cape teen. Cape Argus. https://www.iol.co.za/capeargus/news/ family-battling-to-find-school-placement-forbullied-and-abused-cape-teen-bf7d6bb3-7b2a4b45-ac4d-2597160d2b36

Palm, K. (2019, June 20). School violence: What govt is doing to keep our children and teachers safe. Eyewitness News. https://ewn.co.za/2019/06/20/sa-schoolviolence-what-s-being-done

Rad, D., Roman, A., Dughi, T., Demeter, E., \& Rad, G. (2020). The dynamics of the relationship between just-for-fun online harassment and perceived school safety. INNODOCT 2019 Valencia, 6th-8th November 2019. https:/ / doi.org/10.4995/INN2019. 2019.10233

Raudenbush, S. W., \& Bryk, A. S. (2002). Hierarchical linear models: Applications and data analysis methods (2nd ed.). SAGE.

Reddy, V., Winnaar, L., Juan, A., Arends, F., Harvey, J., Hannan, S., Namome, C., Sekhejane, P., \& Zulu, N. (2020). TIMSS 2019 highlights of South African Grade 9 results in mathematics and science. Human Sciences Research Council. https:/ / www.timss-sa.org/pub lication/timss-2019-highlights-of-south-africangrade-9-results-in-mathematics-and-science 
Ruiz-Hernández, J. A., Pina, D., Puente-López, E., LunaMaldonado, A., \& Llor-Esteban, B. (2020). Attitudes towards school violence questionnaire, revised version: CAHV-28. European Journal of Psychology Applied to Legal Context, 12(2), 61-68. https:/ / doi.org/10.5093/ejpalc2020a8

SA (South Africa). GN (Government Notice). (2017). School infrastructure safety and security guidelines. Department of Basic Education.

SABC. (2021, February 27). Search continues for learner kidnapped in Newlands West. SABC News. https:/ / www.sabcnews.com/sabcnews / searchcontinues-for-newlands-west-kidnapped-learner /

Scheerens, J. (2000). Improving school effectiveness (Vol. 68). UNESCO, International Institute for educational planning.

Scheerens, J. (2008). Een overzichtsstudie naar school-en instructie-effectiviteit [A review of research on school and instructional effectiveness]. University of Twente.

Scheerens, J., Glas, C., \& Thomas, S. M. (2003). Educational evaluation, assessment, and monitoring: A systemic approach. Swets \& Zeitlinger.

Seleka, N. (2020, March 04). Pupil dies, 6 others hospitalised after 'eating tainted chocolate'. News24. https://www.news24.com/news24/southafrica/ news/pupil-dies-6-others-hospitalised-aftereating-tainted-chocolate-20200304

Shay, S. (2020, January 10). Why South Africa's declining maths performance is a worry. University of Cape Town News. http:/ / www.news.uct.ac.za/features / teachingandlearning/-article/2020-01-10-whysouth-africas-declining-maths-performance-is-aworry

Singh, O. (2020, October 24). School principal gunned down in his office. Times Live. https://www.times live.co.za/news/ south-africa/2020-10-24-schoolprincipal-gunned-down-in-his-office/

South African Council for Educators (SACE) (2021). Teachers' safety and security in South African schools: A handbook. South African Council for Educators in partnership with VVOB Education for Development.

Tsesane, T., \& Teffor, S. (2020, November 26). SA's shame: Over 3,000 schools with pit latrines - almost 500 in Limpopo alone. Daily Maverick. https://www. dailymaverick.co.za/article/2020-11-26-sas-shame -over-3000-schools-with-pit-latrines-almost-500-inlimpopo-alone/

Udali, A. J. (2020). Students and staff awareness on school safety measures in public boarding secondary schools in Trans-Nzoia County, Kenya. European Journal of Education Studies, 7(12), 572-584.

United Nations Educational, Social and Cultural Organization. (2017). School violence and bullying: Global status report. Place de Fontenoy, Paris, France. http:/ / unesdoc.unesco.org/images/0024/ 002469/246970e.pdf

Van Dyk, H., \& White, C. J. (2019). Theory and practice of the quintile ranking of schools in South Africa: A financial management perspective. South African Journal of Education, 39(Supplement 1), Article 1820, S1-19. https:/ / doi.org/10.15700/saje.v39ns1a1820

Williford, A., Fite, P., Diaz, K., \& Singh, M. (2021). Associations between different forms of peer victimisation and school absences: The moderating role of teacher attachment and perceived school safety. Psychology in the Schools, 58(1), 185-202. https:/ / doi.org/10.1002/ pits.22438

Zhang, A., Musu-Gillette, L., \& Oudekerk, B.A. (2016). Indicators of school crime and safety: 2015 (NCES 2016079/NCJ 249758). National Center for Education Statistics.

Zhang, A., Wang, K., Zhang, J., \& Oudekerk, B. A. (2019). Indicators of school crime and safety: 2018 (NCES 2019047/NCJ 252571). National Center for Education Statistics.

Zulu, S. (2020, October 21). Bullying video: 2 KZN pupils from Mathole High School suspended. Eyewitness News. https:/ / ewn.co.za/2020/09/08/2-kznpupils-from-mathole-high-school-suspended-forbullying-fellow-pupil

\section{http://www.ejmste.com}

